\title{
Studi Pilot: Peran Heat Shock Protein 60 (Hsp60) dan Kontrol Metabolik terhadap Infeksi Tuberkulosis pada Anak dan Remaja dengan Diabetes Mellitus Tipe-1
}

Aman B. Pulungan, ${ }^{*}$ Karina Sugih Arto, ${ }^{* *}$ Nastiti Kaswandani*

* Departemen Ilmu Kesehatan Anak Fakultas Kedokteran Universitas Indonesia - Rumah Sakit Cipto Mangunkusumo, Jakarta

**Departemen Ilmu Kesehatan Anak, Fakultas Kedokteran Universitas Sumatera Utara - Rumah Sakit Adam Malik, Medan

Latar belakang. Heat shock protein 60 (Hsp60) ditemukan pada individu dengan Diabetes Mellitus (DM) tipe-1 dan merupakan mimikri molekuler Hsp65 pada mycobacterium. Fenomena ini dapat menyebabkan penundaan identifikasi mycobacterium dan memperparah kondisi DM tipe-1.

Tujuan. Studi ini bertujuan untuk meneliti peran Hsp60 dan kontrol metabolik terhadap infeksi tuberkulosis (TB) pada anak dan remaja dengan DM tipe-1.

Metode. Penelitian ini merupakan studi potong lintang yang dilaksanakan di Rumah Sakit Cipto Mangunkusumo. Anak dan remaja dengan DM tipe I yang memenuhi kriteria inklusi dimasukkan dalam sampel penelitian. Setelah memperoleh data dasar, dilakukan pemeriksaan HbA1c, Hsp60, dan IGRA. Dilakukan analisis data.

Hasil. Sebanyak 32 subjek dengan DM tipe-1 diidentifikasi. Insidens infeksi TB yang terdeteksi dengan IGRA pada anak dan remaja dengan DM tipe-1 adalah 12,5\%. Tiga dari empat pasien dengan hasil IGRA positif memiliki nilai HbA1c >9\%. Nilai rerata Hsp60 pada subjek IGRA positif lebih rendah dibandingkan subjek IGRA negatif (1.16 \pm 0.59 vs $115.18 \pm 364.73)$, dengan nilai P>0,05.

Kesimpulan. Tidak didapatkan hubungan signifikan antara Hsp60 dan kontrol glikemik dengan insidens TB pada anak dan remaja dengan DM tipe-1. Hasil ini mungkin dipengaruhi oleh jumlah subjek yang sedikit, penggunaan IGRA untuk mendiagnosis TB pada anak, dan reaktivitas rendah Hsp60 dengan Hsp65. Sari Pediatri 2019;21(2):121-8

Kata kunci: Hsp60, diabetes mellitus tipe-1, tuberkulosis, kontrol glikemik, anak, remaja

\section{The Role of Heat Shock Protein 60 (Hsp60) and Metabolic Control Towards Tuberculosis Infection in Children and Adolescents with Type-1 Diabetes Mellitus: A Pilot Study}

\begin{abstract}
Aman B. Pulungan, ${ }^{*}$ Karina Sugih Arto, ${ }^{* *}$ Nastiti Kaswandani*
Background. Heat shock protein 60 (Hsp60) is found in individuals with Type 1 Diabetes Mellitus (T1DM) and is known to be a molecular mimicry of Hsp65 in mycobacterium. This phenomenon may lead to delay of mycobacterium identification and worsens the T1DM condition.

Objective. This study a ims to investigate the role of $\mathrm{Hsp} 60$ and metabolic control towards tuberculosis (TB) in children a nd adolescents with T1DM.

Methods. A cross-sectional pilot study was conducted in Cipto Mangunkusumo Hospital, Jakarta. Children and adolescents with T1DM were included in the study. After obtaining basic data; HBA1c, HSP60, and IGRA was examined. Data was then analyzed. Results. We identified 32 patients with T1DM. Incidence of TB detected with IGRA

in children and adolescents with T1DM was $12.5 \%$. Three out of four patients with IGRA positive results had HbA1c $>9.0$. The mean Hsp60 value in IGRA-positive subjects was lower compared to negative subjects $(1.16 \pm 0.59$ vs $115.18 \pm 364.73)$, with p level $>0.05$. Conclusion. No significant correlation was found between Hsp60 as well as glycemic control with TB incidence in T1DM children. Study results might be affected by the low number of subjects, the use of IGRA to diagnose TB in children, and low cross-reactivity of Hsp60 with Hsp65. Sari Pediatri 2019;21(2):121-8
\end{abstract}

Keywords: Hsp60, diabetes mellitus type 1, tuberculosis, glycemic control, children, adolescents

Alamat korespondensi: Aman B. Pulungan. Departemen Ilmu Kesehatan Anak Rumah Sakit Cipto Mangunkusumo - Fakultas Kedokteran Universitas Indonesia, Jakarta. Email: amanpulungan@mac.com 


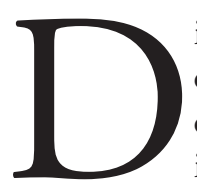
iabetes Mellitus (DM) adalah sindrom dengan ciri hiperglikemia dan disebabkan oleh gangguan fungsi dan/atau sekresi insulin. ${ }^{1}$ Diabetes Mellitus tipe-1 (DM tipe-1) adalah penyakit autoimun di mana sel imunologis menginfiltrasi sel beta pankreas. Umumnya, DM tipe-1 terjadi pada anak. ${ }^{2,3}$ Insidens DM tipe1 pada anak dan remaja di Indonesia tidak diketahui, tetapi Ikatan Dokter Anak Indonesia (IDAI) mencatat peningkatan tujuk kali lipat selama 10 tahun, dari 3,88 per 100 juta penduduk pada tahun 2000 menjadi 28,19 per 100 juta penduduk pada tahun $2010 .^{4}$

Berdasarkan Laporan Tuberkulosis Global 2018 oleh World Health Organization (WHO), ${ }^{5}$ Indonesia merupakan negara dengan beban $\mathrm{TB}$ tertinggi ketiga dan diperkirakan 8\% kasus global terdapat di negara ini. Angka beban TB pada tahun 2017 diperkirakan sebanyak 842,000 , dengan 49,000 di antaranya berusia 0-14 tahun.

Komorbiditas TB dan DM adalah tantangan kesehatan global karena memperburuk keluaran klinis. Telaah sistematis oleh Workneh $\mathrm{dkk}^{6}$ menemukan bahwa median prevalensi DM pada pasien TB di Asia adalah 17\%. Alisjahbana $\mathrm{dkk}^{7}$ di Indonesia melaporkan hubungan kuat antara DM dan TB pada pasien muda yang tidak obesitas. Di Afrika Selatan, ${ }^{8}$ prevalensi TB pada 258 penyandang DM tipe-1 adalah 29,8\%. Peningkatan insidens TB pada anak dan remaja usia 0-14 tahun dengan DM 6,8 kali lebih tinggi dibandingkan subjek non-DM. Remaja dengan DM lebih rentan 10 kali terhadap TB dibandingkan pasien tanpa DM dan risiko TB pulmonal meningkat dengan durasi DM. ${ }^{9}$ Oleh karena itu, Kementerian Kesehatan Republik Indonesia merekomendasikan skrining tuberkulosis pada penyandang DM dewasa dengan mencari gejala klinis dan X-Ray toraks. ${ }^{10}$

Pada dewasa dengan DM, TB berkorelasi dengan kontrol glikemik buruk. ${ }^{11}$ Dalam dua studi, diperoleh hasil kontroversial pada pasien dengan TB-DM. ${ }^{12,13}$ Penelitian di Taiwan ${ }^{12}$ menemukan bahwa pada kelompok DM tidak terkontrol (HbAlc >9\%), proporsi tanda dan gejala klinis TB lebih tinggi dan didapatkan OR untuk hasil pewarnaan Zeihl-Neelsen positif dibandingkan kelompok dengan $\mathrm{HbA1C}<7 \%$ 3,55 (95\% CI 2,4-5,25).

Gen yang diketahui menghubungkan $\mathrm{DM}^{14,15}$ dan $\mathrm{TB}^{16,17}$ adalah SLC11A11. ${ }^{18,19}$ Mutasi gen SLC11a1 teridentifikasi pada beberapa pasien DM tipe- $1 .{ }^{18}$ Gen SLC11 berperan dalam asidifikasi fagosom yang berfungsi untuk melindungi tubuh dari penyakit. ${ }^{19}$ Mutasi dari gen ini menyebabkan gangguan fungsi protein dan menghambat asidifikasi fagosom. Dengan demikian, tercipta kondisi optimal untuk replikasi dan viabilitas bakteri patogen, terutama yang bersifat intraselular seperti TB. ${ }^{20}$

Studi terdahulu menemukan hubungan antara epitope Hsp65 dari mycobacterium dengan DM tipe-1 yang tidak dijumpai pada DM tipe-2..$^{21}$ Pada DM tipe-1, mimikri molekular ditemukan antara Hsp60 dengan mutasi genetik GAD65 dan Hsp65 pada mycobacterium. ${ }^{20}$ Fenomena ini menyebabkan keterlambatan identifikasi Hsp65 pada mycobacterium sebagai antigen dan memperparah kondisi DM tipe1.22

Tertundanya pengenalan mycobacterium oleh sistem imun bawaan juga menyebabkan penundaan respons imun adaptif. Dengan demikian, eliminasi bakteri menjadi terlambat dan jumlah bakteri di paru pun meningkat. Proses ini berhubungan dengan prognosis yang lebih buruk pada penyandang DM dengan infeksi TB dibandingkan pasien tanpa DM. . $^{23-25}$

Studi ini bertujuan untuk mengevaluasi efek kontrol glikemik melalui nilai HbA1c dan kadar Hsp60 terhadap infeksi TB pada anak dan remaja dengan DM tipe-1 dan merupakan yang pertama di Indonesia. Tujuan lain adalah untuk mendapatkan prevalensi infeksi TB pada anak dan remaja dengan DM tipe-1.

\section{Metode}

Penelitian ini merupakan studi potong lintang yang dilaksanakan di Poliklinik Endokrinologi Anak, Rumah Sakit Cipto Mangunkusumo, Jakarta, Indonesia sejak tanggal 1 Mei-1 Juli 2016. Kriteria inklusi adalah anak berusia 5-18 tahun, terdiagnosis dengan DM tipe-1 dengan atau tanpa infeksi TB. Diagnosis infeksi TB dilakukan melalui pemeriksaan Interferon- $\gamma$ Release Assay (IGRA). Subjek dengan kondisi imunokompromais (penggunaan steroid jangka panjang, HIV/AIDS, tumor dengan atau tanpa kemoterapi), autoimun (systemic lupus erythematosus, artritis rematoid, dan lain-lain), penyakit kronik, dan menolak menandatangani persetujuan dieksluski dari penelitian. Perekrutan subjek dilakukan secara konsekutif. 
Diabetes Mellitus tipe-1 didefinisikan berdasarkan kriteria American Diabetes Association: glukosa darah puasa $\geq 126 \mathrm{mg} / \mathrm{dL}(7,0 \mathrm{mmol} / \mathrm{L})$, glukosa darah 2 jam post prandial $\geq 200 \mathrm{mg} / \mathrm{dL}(11,1 \mathrm{mmol} / \mathrm{L})$, atau $\mathrm{HbA} 1 \mathrm{C} \geq 6,5 \%(48 \mathrm{mmol} / \mathrm{mol})$.

\section{Protokol studi}

Karakteristik dasar dan persetujuan dari orang tua atau wali pasien diperoleh. Diagnosis TB dilakukan secara klinis (skor TB IDAI), laboratoris, radiologis, serologi, mikrobiologi, dan temuan patologi anatomi. Jenis dan durasi terapi dicatat. Pemeriksaan IGRA dilakukan untuk mendukung diagnosis infeksi TB. Kedua kelompok (dengan dan tanpa DM tipe-1) diperiksakan IGRA menggunakan QuantiFERON -TB Gold (QFT') ELISA. Sebanyak 100-200 mL whole blood diperoleh dan dibagi dalam tiga jenis tabung QFT (Nil, antigen TB, dan mitogen). Darah diinkubasi lalu dilakukan pemeriksaan ELISA.

Subjek dikelompokkan berdasarkan kadar $\mathrm{HbA1c}$, yaitu terkontrol dan tidak terkontrol. DM tipe-1 terkontrol didefinisikan sebagai kadar HbA1c $\leq 9 \%$. Pemeriksaan HbA1c dilakukan saat diagnosis DM tipe-1 dan tiga bulan setelah terapi menggunakan ion exchange HPLC yang terstandardisasi National Glycohemoglobin Standardization Program (NGSP).

Sampel Hsp60 diperoleh dari darah yang disentrifugasi untuk mendapatkan serum, lalu protokol pemeriksaan Hsp60 dilaksanakan. Nilai Hsp60 diukur pada absorbansi $450 \mathrm{~nm}$. Semua pemeriksaan dan pengumpulan data dilaksanakan oleh dokter peneliti di laboratorium terstandardisasi.

Protokol studi ini disetujui oleh Komite Etik Fakultas Kedokteran Universitas Indonesia - Rumah Sakit Cipto Mangunkusumo, Jakarta.

Analisis data dilakukan menggunakan SPSS versi 19 (IBM, Armonk, NY, Amerika Serkat) dengan tes ANOVA. Untuk mengevaluasi perbedaan nilai HbA1c saat terdiagnosis DM tipe-1 dan setelah terapi DM tipe-1 selama tiga bulan, digunakan uji $\mathrm{T}$ jika distribusi data normal atau uji Mann Whitney jika distribusi tidak normal.

Angka kejadian TB pada subjek dianalisis secara deskriptif. Analisis per protokol digunakan untuk menilai perbedaan infeksi TB pada kelompok kasus dan kontrol menggunakan uji chi square. Faktor lain yang memengaruhi angka kejadian $\mathrm{TB}$ dianalisis secara multivariat menggunakan regresi logistik untuk mendapatkan Odds ratio (OR) dan $95 \%$ confidence interval (CI) pada kelompok dengan DM tipe-1 yang terkontrol dan tidak terkontrol. Nilai $\mathrm{p}<0,05$ dianggap signifikan.

\section{Hasil}

Sebanyak 32 subjek yang terdiri atas 17 perempuan dan 15 laki-laki memenuhi syarat inklusi dan menyetujui protokol penelitian. Karakteristik dasar subjek tertera pada Tabel 1. Pada empat pasien (12,5\%) didapatkan hasil IGRA positif. Rerata usia subjek dengan hasil IGRA positif adalah $14,67 \pm 1,62$ tahun sementara pada subjek dengan IGRA negatif adalah12,80 2,81 tahun. Rerata usia tidak berbeda bermakna pada kedua kelompok IGRA.

Karakteristik antropometri berbeda bermakna pada kedua kelompok IGRA. Pada subjek dengan hasil IGRA positif, berat badan secara signifikan lebih tinggi dibandingkan kelompok IGRA negatif $(55,00$ $\pm 10,03 \mathrm{~kg}$ vs $39,64 \pm 11,32 \mathrm{~kg} ; \mathrm{p}=0,015)$. Subjek yang termasuk dalam kelompok IGRA positif memiliki nilai berat badan terhadap usia $(p=0,071)$ dan indeks massa tubuh (IMT) terhadap usia $(\mathrm{p}=0,001)$ yang lebih tinggi dibandingkan subjek IGRA negatif.

Tabel 2 menunjukkan karakteristik metabolik DM tipe-1 pada subjek. Pada kelompok IGRA positif, durasi penyakit pada positif lebih lama $(4,39 \pm 3,12$ vs 3,75 $\pm 3,09$ tahun) dan nilai $\mathrm{HbA1c}$ lebih rendah $(9,22 \pm 1,92$ vs $10,65 \pm 3,66)$. Namun, tidak didapatkan perbedaan signifikan antara kelompok IGRA positif dan negatif. Sebagian besar subjek pada kedua kelompok tidak pernah mengalami ketoasidosis diabetik (KAD).

Semua subjek mengaku pernah mendapatkan imunisasi BCG, tetapi parut BCG tidak ditemukan pada 15 pasien. Status imunisasi dan adanya parut BCG tidak berbeda bermakna antara kedua kelompok IGRA. Tidak terdapat kontak TB pada sebagian besar pasien (29/32). Dari tiga pasien dengan kontak TB, satu subjek termasuk dalam kelompok IGRA positif. Gejala TB aktif, yaitu batuk persisten, demam lebih dari dua minggu, penurunan berat badan, keringat malam, sesak, atau pembesaran kelenjar getah bening tidak didapatkan pada subjek penelitian. Karakteristik TB pada sampel penelitian tertera pada Tabel 3 .

Walaupun subjek dengan IGRA positif memiliki rerata nilai $\mathrm{HbA1c}$ lebih tinggi, tidak didapatkan 
Tabel 1. Karakteristik dasar subjek penelitian

\begin{tabular}{|c|c|c|c|}
\hline Karakterisitik & $\begin{array}{l}\text { IGRA Positif } \\
(\mathrm{n}=4)\end{array}$ & $\begin{array}{l}\text { IGRA Negatif } \\
(\mathrm{n}=28)\end{array}$ & $\mathrm{p}$ \\
\hline Jenis kelamin (n, \%) & & & 0,337 \\
\hline Perempuan & $3(75)$ & $14(50)$ & \\
\hline Laki-laki & $1(25)$ & $14(50)$ & \\
\hline Usia (tahun, rerata $\pm S D$ ) & $14,67 \pm 1,62$ & $12,80 \pm 2,81$ & 0,210 \\
\hline Berat badan $(\mathrm{kg}$, rerata $\pm S \mathrm{SD})$ & $55,00 \pm 10,03$ & $39,63 \pm 11,32$ & 0,015 \\
\hline Tinggi badan $(\mathrm{cm}$, rerata $\pm \mathrm{SD})$ & $155,50 \pm 8,70$ & $145,38 \pm 12,78$ & 0,138 \\
\hline Berat badan terhadap usia (n, \%) & & & 0,071 \\
\hline Normal & $3(75)$ & $24(85,7)$ & \\
\hline Berat badan kurang & $1(25)$ & 0 & \\
\hline Berat badan sangat kurang & 0 & $4(14,3)$ & \\
\hline Tinggi badan terhadap usia (n, \%) & & & 0,284 \\
\hline Normal & $4(100)$ & $24(85,7)$ & \\
\hline Pendek & 0 & $2(14,2)$ & \\
\hline IMT terhadap usia (n, \%) & & & 0,001 \\
\hline Normal & $1(25)$ & $27(9,4)$ & \\
\hline Overweight dan obesitas & $3(75)$ & $1(3,6)$ & \\
\hline
\end{tabular}

Tabel 2. Karakteristik metabolik DM tipe-1 pada subjek

\begin{tabular}{lcccc}
\hline Karakteristik & $\begin{array}{c}\text { IGRA positif } \\
(\mathrm{n}=4)\end{array}$ & $\begin{array}{c}\text { IGRA negatif } \\
(\mathrm{n}=28)\end{array}$ & $\mathrm{p}$ & OR \pm CI 95\% \\
\hline $\begin{array}{l}\text { Durasi DM sejak pertama } \\
\text { terdiagnosis }(\text { tahun, rerata } \pm \text { SD) }\end{array}$ & $3,75 \pm 3,09$ & $4,39 \pm 3,12$ & 0,702 & \\
HbA1C (rerata \pm SD) & $10,65 \pm 3,66$ & $9,22 \pm 1,92$ & 0,226 & \\
HbA1C & $1(25)$ & $16(57,1)$ & & \\
Terkontrol $(\leq 9 \%)$ & $3(75)$ & $12(42,9)$ & & \\
Tidak terkontrol $(>9 \%)$ & & & 0,221 & $4,00(0,37-43,38)$ \\
Riwayat KAD $(\mathrm{n}, \%)$ & $1(25)$ & $12(42,9)$ & & \\
$\quad$ Ada & $3(75)$ & $16(57,1)$ & & \\
Tidak ada & & & \\
\hline
\end{tabular}

Tabel 3. Karakteristik TB pada subjek

\begin{tabular}{lccc}
\hline Karakteristik & $\begin{array}{c}\text { IGRA positif } \\
(\mathrm{n}=4)\end{array}$ & $\begin{array}{c}\text { IGRA negatif } \\
(\mathrm{n}=28)\end{array}$ & $\mathrm{p}$ \\
\hline Parut BCG (n, \%) & & & 0,337 \\
Ada & $3(75)$ & $14(50)$ & \\
Tidak ada & $1(25)$ & $14(50)$ & 0,316 \\
Kontak TB (n, \%) & & & \\
Ada & $1(25)$ & $2(7,1)$ & \\
Tidak ada & $3(75)$ & $26(92,9)$ & \\
\hline
\end{tabular}

hubungan yang signifikan antara hasil IGRA positif dengan kontrol glikemik buruk (HbA1c $>9,0 \% ; p=0,221$ ) (Tabel 2). Lebih dari setengah subjek dengan IGRA negatif memiliki kontrol glikemik baik dengan HbA1c $\leq 9 \%$, OR 4,00 (CI 95\% 0,37-43,38).
Empat anak dengan IGRA positif memiliki nilai Hsp60 di bawah normal (3,125-100 ng/mL). Nilai Hsp60 pada subjek IGRA negatif bervariasi, yaitu dari 0-1900 ng/mL. Walaupun tidak didapatkan hubungan yang bermakna antara nilai Hsp60 dan hasil IGRA, 
Tabel 4. Hubungan antara nilai Hsp60 dan hasil IGRA

\begin{tabular}{lccc}
\hline Karakteristik & $\begin{array}{c}\text { IGRA positif } \\
(\mathrm{n}=4)\end{array}$ & $\begin{array}{c}\text { IGRA negatif } \\
(\mathrm{n}=28)\end{array}$ & $\mathrm{p}$ \\
\hline Rerata Hsp60 $\pm \mathrm{SD}(\mathrm{ng} / \mathrm{mL})$ & $1,16 \pm 0,59$ & $115,18 \pm 364,73$ & 0,608 \\
Hsp60 $(\mathrm{ng} / \mathrm{mL}), n(\%)$ & & & \\
$<3,125$ & 4 & 21 & \\
$3,125-100$ & 0 & 3 \\
$100-1000$ & 0 & 3 & \\
$>1000$ & 0 & 1 & \\
\hline
\end{tabular}

rerata nilai Hsp60 pada subjek IGRA positif lebih rendah dibandingkan subjek IGRA negatif $(1,16 \pm 0,59$ vs $115,18 \pm 364,73 \mathrm{ng} / \mathrm{mL} ; \mathrm{p}=0,608)$. Hubungan antara nilai Hsp60 dan hasil IGRA tertera pada Tabel 4.

\section{Pembahasan}

Penelitian ini merupakan studi pilot untuk menentukan efek Hsp60 terhadap infeksi TB, yang secara teori merupakan mimikri molekuler dari Hsp65 yang dimiliki oleh Mycobacterium tuberculosis. Ditemukan hasil IGRA positif pada 12,5\% subjek DM tipe-1. Hasil ini serupa dengan penelitian di India $(10,1 \%)$, tetapi lebih rendah dibandingkan studi di Afrika Selatan yang menemukan bahwa 30\% anak dengan DM tipe-1 mengalami infeksi TB. Studi ini juga melaporkan bahwa anak dengan DM tipe-1 memiliki risiko 6,8 kali lebih tinggi terinfeksi TB. ${ }^{8,26}$ Beberapa hipotesis mengenai peningkatan risiko TB pada penyandang DM tipe-1 adalah akibat kerusakan imunitas selular. Pada individu dengan DM tipe-1, kadar limfosit T, transformasi sel, dan aktivitasi makrofag untuk mengeliminasi infeksi mycobacterium berkurang. Dengan demikian, terjadi gangguan eliminasi bakteri yang menyebabkan sifat mycobacterium semakin patogenik.

Terdapat temuan menarik pada studi ini mengenai hubungan infeksi TB dengan berat badan. Indonesia merupakan negara berkembang dengan beban ganda malnutrisi. Di Indonesia, angka gizi kurang masih tinggi sementara insidens gizi berlebih meningkat. ${ }^{27}$ Subjek penelitian menunjukkan tren gizi berlebih, dilihat dari rendahnya nilai tinggi badan terhadap usia. Sebaliknya, nilai IMT terhadap usia yang tinggi. Hasil ini sesuai dengan literatur terdahulu yang menyatakan bahwa angka gizi berlebih lebih tinggi di daerah urban seperti Jakarta dibandingkan daerah rural. Pada studi ini didapatkan hubungan yang bermakna antara malnutrisi dengan infeksi TB. Studi global oleh Odone $\mathrm{dkk}^{28}$ melaporkan bahwa pada subjek tanpa DM, IMT berkorelasi negatif dengan insidens TB. Walaupun IMT tinggi diduga protektif terhadap infeksi TB pada individu tanpa DM. Sebaliknya, IMT tinggi berhubungan dengan komorbiditas yang lebih berat pada pasien DM.

Tidak didapatkan hubungan bermakna antara kontak TB dengan hasil IGRA positif. Sebaliknya, penelitian terdahulu menemukan bahwa kontak TB merupakan faktor risiko infeksi TB pada anak dengan DM tipe-1. Kontak TB pada individu yang tidak pernah terinfeksi mycobacterium meningkatkan risiko infeksi laten. Subjek DM dengan infeksi mycobacterium memiliki probabilitas reaktivasi $\mathrm{TB}$ lebih tinggi dibandingkan individu tanpa DM. ${ }^{29}$

Pada penelitian ini, IGRA digunakan untuk mendiagnosis TB. Sensitivitas dan spesifisitas IGRA serum untuk mendiagnosis $\mathrm{TB}$ pada anak secara berturut-turut adalah 67-86\% dan 93-98\%. ${ }^{30}$ Sensitivitas IGRA tidak dipengaruhi oleh gangguan regulasi imunitas yang terjadi pada pasien dengan komorbiditas DM-TB. Interpretasi harus dilakukan secara hati-hati karena IGRA bukan merupakan pemeriksaan baku emas infeksi TB pada anak. Berdasarkan beberapa studi kasus, karakteristik imunologis pada bayi dan anak dapat memengaruhi nilai IGRA menjadi lebih rendah yang mungkin diakibatkan oleh limfositopenia. ${ }^{31}$ Pada neonatus dan anak usia muda, fungsi makrofag dan sel dendritik lebih rendah, begitu juga dengan produksi IFN- $\gamma$ yang rendah sebagai respons mitogenik. ${ }^{30}$ Dengan demikian, usia dapat menjadi faktor perancu terhadap hasil IGRA pada studi ini.

Pada dewasa dengan DM tipe-1, TB berasosiasi dengan peningkatan mortalitas dan morbiditas. Hubungan kausal antara DM tipe-1 dan TB tidak diketahui secara pasti, apakah kontrol glikemik yang buruk menjadi predisposisi terhadap infeksi TB atau kontrol glikemik buruk disebabkan oleh infeksi TB. 
Aman B Pulungan dkk: Studi pilot: Peran Hsp60 dan kontrol metabolik terhadap infeksi TB pada anak dan remaja dengan DM tipe-1

Tidak didapatkan hubungan signifikan antara durasi sakit DM tipe-1 dengan insidens TB, seperti diutarakan oleh penelitian sebelumnya. ${ }^{8}$ Dalam penelitian ini, ditemukan bahwa anak dan remaja dengan DM tipe-1 tidak terkontrol (HbA1C $\geq 9 \%$ ) memiliki risiko empat kali lipat lebih tinggi terkena infeksi TB walaupun tidak signifikan secara statistik. Hasil ini mungkin diakibatkan oleh jumlah sampel yang sedikit; pada penelitian dengan jumlah subjek lebih besar ditemukan hubungan yang bermakna. ${ }^{8,9,32}$

Inflamasi kronik akibat kontrol glikemik buruk dapat menjadi predisposisi infeksi TB karena penurunan respons Th1 dan produksi sitokin (IL-12, IFN- $\gamma$, dan nitrit oksida). ${ }^{11,24}$ Penelitian sebelumnya melaporkan bahwa kadar IFN- $\gamma$ lebih rendah pada pasien dengan DM tidak terkontrol, dan kadarnya berhubungan secara signifikan dengan nilai HbA1c. ${ }^{33}$ Hiperglikemia juga diketahui mengganggu aktivitas makrofag, ${ }^{34}$ respons humoral, dan sintesis immunoglobulin. ${ }^{35}$

Penelitian multisentra di Taiwan ${ }^{12}$ melaporkan bahwa pada kelompok dengan kontrol metabolik buruk (HbA1C $>9 \%$ ), proporsi gejala TB lebih besar dibandingkan pada kelompok dengan $\mathrm{HbA} 1 \mathrm{C}<7 \%$. Penelitian lain di Denmark ${ }^{13}$ melaporkan bahwa terdapat peningkatan insidens TB pada pasien dewasa dengan DM tidak terkontrol (HbA1C >8\%) dibandingkan pasien tanpa TB meskipun tidak signifikan secara statistik.

Studi ini merupakan yang pertama mengevaluasi nilai Hsp60 sebagai faktor predisposisi infeksi TB pada anak dan remaja dengan DM tipe-1. Protein heat shock (Hsp) terbentuk ketika tubuh terpajan stress seperti inflamasi, infeksi, tumor, atau penyakit autoimun, termasuk diabetes mellitus. ${ }^{20,36}$ Dua studi mendapatkan peningkatan titer antibodi Hsp60 pada tikus dengan diabetes tanpa obesitas. ${ }^{37}$ Pada manusia ditemukan peningkatan respons sel T terhadap Hsp60. ${ }^{38}$

Hasil pada penelitian ini berlawananan dengan penelitian sebelumnya yang menemukan peningkatan kadar Hsp60 pada pasien DM tipe-1. Kadar Hsp60 subjek penelitian ternyata normal-rendah yang diduga dipengaruhi oleh perubahan kadar Hsp60 dengan durasi penyakit DM. Penelitian terdahulu menemukan bahwa pada pasien yang baru terdiagnosis DM tipe1, kadar Hsp60 meningkat sampai enam minggu pascadiagnosis lalu menurun. Fenomena ini tidak dapat dijelaskan dalam penelitian ini karena sebagian besar subjek telah terdiagnosis dengan DM tipe-1 selama lebih dari enam minggu.

Empat subjek penelitian memiliki kadar Hsp60 lebih tinggi dari $100 \mathrm{ng} / \mathrm{mL}$ dan terdiagnosis DM sejak 5-7 tahun yang lalu. Dengan demikian, diobservasi bahwa kadar Hsp60 meningkat 5-7 tahun setelah diagnosis DM, lalu menurun di bawah batas normal $(<3,125 \mathrm{ng} / \mathrm{mL})$.

Beberapa kekurangan dari penelitian ini adalah jumlah sampel yang kecil karena merupakan studi pilot. Hubungan kausal antarvariabel tidak dapat ditentukan karena merupakan studi potong lintang.

\section{Kesimpulan}

Insidens TB yang terdeteksi melalui IGRA pada anak dengan DM tipe-1 adalah 12,5\%. Kontrol glikemik yang buruk tidak berhubungan secara signifikan dengan infeksi $\mathrm{TB}$, tetapi penelitian ini merupakan studi pilot dengan 30 subjek. Tidak didapatkan hubungan yang bermakna antara kadar Hsp60 dengan infeksi tuberkulosis pada anak dan remaja dengan DM tipe-1. Hasil ini mungkin dipengaruhi oleh reaktivitas silang yang rendah antara Hsp60 dengan Hsp65 mycobacterium, jumlah sampel yang rendah, dan penggunaan IGRA untuk mendiagnosis TB. Oleh karena itu, dibutuhkan penelitian lebih lanjut dengan desain kohort atau randomized controlled trials dengan jumlah sampel yang besar.

\section{Daftar pustaka}

1. Thomas CC, Philipson LH. Update on diabetes classification. Med Clin North Am 2015;99:1-16.

2. American Diabetes Association. 2. Classification and Diagnosis of Diabetes. Diabetes Care 2016;39 Suppl 1: S13-22.

3. Bluestone JA, Herold K, Eisenbarth G. Genetics, pathogenesis and clinical interventions in type 1 diabetes. Nature 2010;464:1293-300.

4. Pulungan AB, Batubara JRL, Tridjaja B, Soesanti F, Fadiana G, Annisa D, dkk. Profile of Diabetic Ketoacidosis in Children with Diabetes Mellitus in A Tertiary Care Hospital in Jakarta: A Retrospective Study. Acta Scientific Paediatrics 2019;2:24-9.

5. World Health Organization. Global Tuberculosis Report 2018. France: World Health Organization; 2018.

6. Workneh MH, Bjune GA, Yimer SA. Prevalence and associated factors of tuberculosis and diabetes mellitus comorbidity: A systematic review. PLoS One 2017;21:e0175925. 
Aman B Pulungan dkk: Studi pilot: Peran Hsp60 dan kontrol metabolik terhadap infeksi TB pada anak dan remaja dengan DM tipe-1

7. Alisjahbana B, van Crevel R, Sahiratmadja E, den Heijer M, Maya A, Istriana E. Diabetes mellitus is strongly associated with tuberculosis in Indonesia. Int J Tuberc Lung Dis 2006;10:696-700.

8. Webb EA, Hesseling AC, Schaaf HS, dkk. High prevalence of Mycobacterium tuberculosis infection and disease in children and adolescents with type 1 diabetes mellitus. Int J Tuberc Lung Dis 2009; 13: 868-74.

9. Root $\mathrm{H}$. The association of diabetes and tuberculosis. N Engl J Med 1934;210:127-47.

10. Indonesian Ministry of Health. Consensus of Tuberculosis and Diabetes Mellitus (TB-DM) Management in Indonesia. Jakarta: Indonesian Ministry of Health; 2015.

11. Stevenson CR, Critchley JA, Forouhi NG, dkk. Diabetes and the risk of tuberculosis: a neglected threat to public health? Chronic Illn 2007;3:228-45.

12. Chiang CY, Bai KJ, Lin HH, dkk. The influence of diabetes, glycemic control, and diabetes-related comorbidities on pulmonary tuberculosis. PLoS One 2015;10: e0121698.

13. Leegaard A, Riis A, Kornum JB, dkk. Diabetes, glycemic control, and risk of tuberculosis: a population-based casecontrol study. Diabetes Care 2011;34:2530-5.

14. Takahashi K, Satoh J, Kojima Y, dkk. Promoter polymorphism of SLC11A1 (formerly NRAMP1) confers susceptibility to autoimmune type 1 diabetes mellitus in Japanese. Tissue Antigens 2004;63: 231-6.

15. Yang JH, Downes K, Howson JM, dkk. Evidence of association with type 1 diabetes in the SLC11A1 gene region. BMC Med Genet 2011;12: 59.

16. Malik S, Abel L, Tooker H, dkk. Alleles of the NRAMP1 gene are risk factors for pediatric tuberculosis disease. Proc Natl Acad Sci USA 2005;102:12183-8.

17. Abe T, Iinuma Y, Ando M, dkk. NRAMP1 polymorphisms, susceptibility and clinical features of tuberculosis. J Infect 2003;46:215-20.

18. Paccagnini D, Sieswerda L, Rosu V, dkk. Linking chronic infection and autoimmune diseases: Mycobacterium avium subspecies paratuberculosis, SLC11A1 polymorphisms and type-1 diabetes mellitus. PLoS One 2009;4:e7109

19. Dai YD, Marrero IG, Gros P, Zaghouani H, Wicker LS, Sercarz EE. Slc11a1 enhances the autoimmune diabetogenic T-cell response by altering processing and presentation of pancreatic islet antigens. Diabetes 2009;58:156-64.

20. Dow CT. M. paratuberculosis Heat Shock Protein 65 and Human Diseases: Bridging Infection and Autoimmunity. Autoimmune Dis 2012;2012:150824.

21. Rosu V, Ahmed N, Paccagnini D, dkk. Specific immunoassays confirm association of Mycobacterium avium Subsp. paratuberculosis with type-1 but not type- 2 diabetes mellitus.
PLoS One 2009; 4:e4386.

22. Rani PS, Babajan B, Tulsian NK, Begum M, Kumar A, Ahmed N. Mycobacterial Hsp65 potentially cross-reacts with autoantibodies of diabetes sera and also induces (in vitro) cytokine responses relevant to diabetes mellitus. Mol Biosyst 2013;9:2932-41.

23. Martinez N, Kornfeld H. Diabetes and immunity to tuberculosis. Eur J Immunol. 2014; 44: 617-26.

24. Dooley KE, Chaisson RE. Tuberculosis and diabetes mellitus: convergence of two epidemics. Lancet Infect Dis 2009;9:737-46.

25. Skowronski M, Zozulinska-Ziolkiewicz D, BarinowWojewodzki A. Tuberculosis and diabetes mellitus - an underappreciated association. Arch Med Sci 2014;10:1019-27.

26. Nair A, Guleria R, Kandasamy D, dkk. Prevalence of pulmonary tuberculosis in young adult patients with Type 1 diabetes mellitus in India. Multidiscip Respir Med 2016;11:22.

27. Hanandita W, Tampubolon G. The double burden of malnutrition in Indonesia: Social determinants and geographical variations. SSM - Population Health 2015;1:16-25.

28. Odone A, Houben RM, White RG, Lonnroth K. The effect of diabetes and undernutrition trends on reaching 2035 global tuberculosis targets. Lancet Diabetes Endocrinol 2014;2:754-64.

29. Restrepo B, Schlesinger L. Impact of diabetes on the natural history of tuberculosis. Diabetes Res Clin Pract 2014; 106: 191-9.

30. Sollai S, Galli L, de Martino M, Chiappini E. Systematic review and meta-analysis on the utility of Interferon-gamma release assays for the diagnosis of Mycobacterium tuberculosis infection in children: a 2013 update. BMC Infect Dis 2014;14 Suppl 1:S6.

31. Carvalho AC, Schumacher RF, Bigoni S, dkk. Contact investigation based on serial interferon-gamma release assays (IGRA) in children from the hematology-oncology ward after exposure to a patient with pulmonary tuberculosis. Infection 2013;41:827-31.

32. Restrepo BI, Fisher-Hoch SP, Pino PA, dkk. Tuberculosis in poorly controlled type 2 diabetes: altered cytokine expression in peripheral white blood cells. Clin Infect Dis 2008;47: 634-41.

33. Tsukaguchi K, Okamura $\mathrm{H}$, Ikuno $\mathrm{M}$, dkk. [The relation between diabetes mellitus and IFN-gamma, IL-12 and IL-10 productions by $\mathrm{CD} 4+$ alpha beta $\mathrm{T}$ cells and monocytes in patients with pulmonary tuberculosis]. Kekkaku 1997;72: 617-22.

34. MacRury SM, Gemmell CG, Paterson KR, MacCuish AC. Changes in phagocytic function with glycaemic control in diabetic patients. J Clin Pathol 1989;42:1143-7.

35. Ardawi M, Nasrat H, Bahnassy A. Serum immunoglobulin concentrations in diabetic patients. Diabet Med 1994;11:384-7.

36. Randons J. HSP60: Disease relevance. Diakses 13 Juli 2016. Didapat dari: http://hsp60.com/disease-relevancel. 
Aman B Pulungan dkk: Studi pilot: Peran Hsp60 dan kontrol metabolik terhadap infeksi TB pada anak dan remaja dengan DM tipe-1

37. Elias D, Markovits D, Reshef T, van der Zee R, Cohen IR. Induction and therapy of autoimmune diabetes in the nonobese diabetic (NOD/Lt) mouse by a $65-\mathrm{kDa}$ heat shock protein. Proc Natl Acad Sci USA 1990; 87:1576-80.
38. Abulafia-Lapid R, Elias D, Raz I, Keren-Zur Y, Atlan H, Cohen IR. $T$ cell proliferative responses of type 1 diabetes patients and healthy individuals to human hsp60 and its peptides. J Autoimmun 1999;12:121-9. 